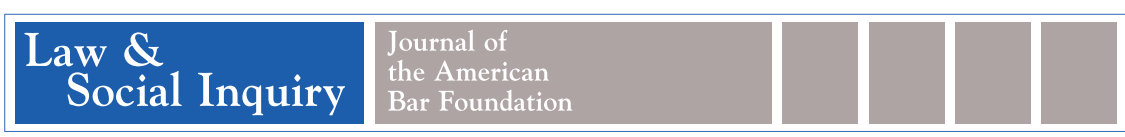

Law E3 Social Inquiry

Volume 42, Issue 1, 49-59, Winter 2017

\title{
Forceful Self-Help and Private Voice: How Schauer and McAdams Exaggerate a State's Ability to Monopolize Violence and Expression
}

Robert C. Ellickson

Frederick Schauer's The Force of Law (2015) and Richard McAdams's The Expressive Powers of Law (2015) are noteworthy contributions. However, both authors exaggerate the importance of law, as opposed to other means of social control. Schauer largely omits the role that self-help measures, ranging from negative gossip to violent self-defense, play in deterring misconduct. Contrary to Max Weber, the state in practice cannot monopolize the legitimate use of physical force. McAdams valuably analyzes law's potentially expressive effects. He might have devoted more attention, however, to identifying the contexts in which state speech tends to be more salient than private speech, such as a statement by the pope or another esteemed private pundit.

\section{INTRODUCTION}

Fred Schauer's and Richard McAdams's books impressively enrich the legal literature. Their analyses are clear-headed and largely persuasive. Particular strengths are Schauer's skeptical outlook and lively prose, and McAdams's command of game theory and inventive turn of mind. A committed researcher will value the footnotes in both works, which brim with citations to sources in a wide variety of disciplines.

McAdams's work fruitfully complements Schauer's. Schauer generally endorses John Austin's account of law, which emphasizes the backdrop of force that lies behind state commands. But Schauer shows that Austin's account is incomplete because law can be effective even when not backed by force. McAdams highlights two forms of legal expression, both of which illustrate the incompleteness of the Austinian view. A state can influence behavior by providing a focal point, or by conveying information about risks or popular sentiments. ${ }^{1}$ When a state acts in either of these ways, the effectiveness of its efforts is seldom attributable to its iron

Robert Ellickson is Walter E. Meyer Professor Emeritus of Property and Urban Law and Professorial Lecturer in Law at Yale Law School. He may be contacted at robert.ellickson@yale.edu.

1. In some passages, Schauer roughly anticipates McAdams's central theses (Schauer 2015, 103-06, 146), and expressly states that a law may function as a "focal point" (105). 
hand. McAdams's picture of political life is far more cheerful than that drawn by public choice theorists. Instead of simply catering to the preferences of interest groups, a McAdamsian legislator uses voice to foster bottom-up cooperation.

My central theme in this review is that Schauer's and McAdams's generally admirable analyses both are overly state-centered. Most legal scholars are legal centralists, that is, prone to exaggerate the influence of law on behavior. Why is an unprovoked pedestrian unlikely to assault a stranger? Holmes's discussion of the "bad man" (1897, 460-61) provides a legal-centralist explanation: the pedestrian's fear of sanctions that a state might impose. But this perspective downplays the influence of nonlegal portions of the overall system of social control. For many pedestrians, the most potent constraints against committing an assault would not be law, but their own internalized norms of proper conduct, fear of retaliation, and reputational concerns.

Schauer and McAdams are far less prone than most law professors to succumb to legal centralism. ${ }^{2}$ Nonetheless, in these two books, they err in that direction. Schauer pays scant attention to the role of private self-help-the force that individuals instinctively use to prevent assaults on their persons and property. McAdams, while cogently demonstrating that state actors can use expressive acts to promote cooperation, understates the potential power, in similar contexts, of private expression.

After developing these principal points, I turn to a narrower topic: the role of private enterprises and membership associations in the overall system of social control. A pedestrian might refrain from assaulting a stranger in part out of fear that an organization with which he is associated would respond by sanctioning him. A corporation, for example, might fire a worker who, without provocation, had assaulted a coworker while both were walking to a local eatery for lunch. A homeowners' association might suspend a punch-prone member's rights to use the communal swimming pool. Schauer and McAdams both refer at places to private associations, but seem puzzled about how these entities fit into the overarching system of social control. The final section offers some thoughts on that topic.

\section{PRIVATE FORCE COMMONLY IS A GREATER DETERRENT THAN STATE FORCE}

Max Weber $(1946,129)$ famously, but misleadingly, asserted that "the state ... successfully claims the monopoly of the legitimate use of physical force within a

2. In various writings, both authors have stressed, for example, the power of diffusely enforced social norms. McAdams (1997) has made pioneering contributions to the law and norms literature, and a subsequent book explicitly discusses self-help $(2015,68)$. Schauer recognizes the possible power of internalized norms of morality $(2015,32,49-51)$, culture (73-74), reputational concerns (132-35), and externally enforced norms (140-53). 
given territory." Schauer (2015, 129; see also 164) approvingly paraphrases Weber's statement, and proceeds to emphasize "the state's ability to direct people with guns and uniforms" either to apply force or to administer a variety of nonphysical sanctions.

Weber and Schauer both underestimate the role of private self-help, including forceful self-help, in the overall system of social control. Consider the memorable opening moments of Quentin Tarantino's film Pulp Fiction. The scene begins with the portrayal of a conversation between two hoodlums sitting in a booth of a coffee shop. The two talk themselves into pulling out pistols and robbing not only the cash register, but also the dozens of other coffee shop patrons. The plan is wacky, as the film's title suggests it should be. A rational robber would seek to victimize a lone person walking on a desolate street, not a crowd in a coffee shop. One or more of the coffee shop patrons might resist and succeed in disarming the would-be robbers. In its final episode, Pulp Fiction shows the denouement of the attempted coffee shop robbery. The hoodlums unhappily discover that several of the other diners are carrying firearms, now drawn and pointed in their direction. Coffee shops tend to be robberyfree. The efforts of police officers and courts, of course, contribute to this result. However, as Pulp Fiction implies, decentralized acts of self-help, with or without weaponry, also potently deter crime (Polsby 1986, 97), especially in well-trafficked spaces.

Every legal system authorizes individuals to engage in reasonable amounts of self-help_violent when necessary-to protect not only their own property and bodily integrity, but also the property and bodily integrity of others (Wechsler and Michael 1937, 736; Johnson 2006; Kopel 2008). To lawyers, the doctrines of selfdefense in tort and criminal law perhaps are the most familiar of these rules. The Second Amendment's conferral of a right to bear arms can be interpreted as an affirmation of the legitimacy of this decentralized approach.

Weber might have characterized the legal rules that legitimize reasonable acts of self-defense as state delegations of authority to the diffuse members of the public, but monopoly power over a service implies a high degree of discretionary control over the provision of the monopolized service (Rasmusen forthcoming). For three reasons, a state is inherently unable to manage individuals' self-help endeavors closely.

First, monopoly implies a degree of control over the use of force that a state in practice can never attain. Because state officials cannot be everywhere, they cannot realistically review, ex ante, the appropriateness of an individual's incipient act of self-help, such as a punch to ward off an unprovoked assault. In practice, state officials at most can review, ex post, the legitimacy of a prior act of self-help, that is, determine whether it indeed was justified under the circumstances. This is a pale form of monopoly, compared to total ex ante control.

Second, empirical studies demonstrate that in most contexts members of the public have minimal knowledge of legal rules (Ellickson 1991, 144-45; Kim 1997).

3. Rawls $(1993,136)$ makes a similar error: "[P]olitical power is always coercive power backed up by the government's use of sanctions, for government alone has the authority to use force in upholding its laws. In a constitutional regime the special feature of the political relation is that political power is ultimately the power of the public, that is, the power of free and equal citizens as a collective body." 
Darley, Carlsmith, and Robinson (2001) have found that popular knowledge of the legal rules governing the legitimacy of the use of force in self-help defense of person and property is similarly limited. ${ }^{4}$ A state's ex post sanctions aimed at deterring undue exercises of self-help thus can be expected to have minimal effects on the incidence of self-help behavior. Monopoly implies a greater degree of efficacy.

Third, and relatedly, an individual's acts to defend person or property typically are instinctive. ${ }^{5}$ Suppose a state had a well-publicized law that prohibited a victim from resisting a rape attempt. Many targets of rape attempts nonetheless would instinctively engage in self-defense. The ubiquity of the legal rules that legitimize reasonable acts of self-defense indicates that a state has no realistic choice other than to decentralize to individuals the authority to administer measured violence against wrongdoers. A true monopolist would not be so fettered. To say that the state legitimizes self-help is like saying that the state legitimizes acts of breathing. If some acts of violent self-help are inherently legitimate, the state does not in fact monopolize the legitimate use of force. ${ }^{6}$

Weber's conception of a state monopoly of the legitimate use of force thus warrants amendment. ${ }^{7}$ As Sandy Levinson $(1989,650)$ has noted, Weber's "is a profoundly statist definition, the product of a specifically German tradition of the (strong) state rather than of a strikingly different American political tradition that is fundamentally mistrustful of state power and vigilant about maintaining ultimate power, including the power of arms, in the populace." An alternative vision, sounder than Weber's, of the state's role in controlling violence is this:

1. In every society, some individuals, without provocation, at times violently prey on others' persons and property.

2. Those attacked, and perhaps bystanders as well, are inherently prone to use selfhelp measures, perhaps also violent, to ward off or punish these acts of predation.

3. A state, unable wholly to prevent the two forms of private violence listed above, invariably attempts to regulate both forms, commonly with sanctions applied after the fact.

\section{MCADAMS'S INSUFFICIENT DISCUSSION OF THE COMPARATIVE INSTITUTIONAL ADVANTAGES OF THE STATE AS SPEAKER}

McAdams convincingly shows that the pronouncements of a democratic government-for example, its statutes, regulations, and officials' acts and declarations - may serve both to establish focal points and to provide information. It is intuitively plausible that, in some contexts, state officials would be uniquely wellsituated to carry out a valuable expressive function. Who better than Congress

4. A few states require an applicant for a gun permit to receive training in the law of self-defense (Enright 2015, 920-21). I am not aware of studies on the effectiveness of these educational efforts.

5. Throughout the animal kingdom, possessors of resources commonly are willing to fight to keep them (Gintis 2007).

6. In addition, a state is unlikely in practice to be able to control victims' use of potentially powerful nonviolent self-help measures, such as negative gossip and shunning (Ellickson 1991, 211-19).

7. A state may succeed, however, to the benefit of its populace, in preventing the emergence of private armies. See Grechenig and Kolmar (2014); compare Acemoglu, Robinson, and Santos (2013). 
could decide when Daylight Savings Time is to begin and end? Would not a uniformed police officer have more success in directing traffic than a bystander (a volunteer who recurrently appears in The Expressive Power of Law)? And a legislative enactment might indeed be the best means of informing a citizenry about shifts in public opinion on a controversial topic, such as same-sex marriage.

But, especially in a society that protects freedom of expression, countless nonstate actors also engage in speech. McAdams, of course, recognizes this. He cites countless examples of private actors-arbitrators, chess federations, bystanders directing traffic - who provide focal points. A key challenge is to identify the contexts in which lawmakers have an inherent comparative advantage, compared to nonstate actors, in expressive activity. McAdams (2015) addresses this central issue in several passages (see especially $62-63,122-27$ ), but his discussion is overly statecentered. Just as Schauer overemphasizes state force as opposed to private force, McAdams overemphasizes the power of state speech as opposed to private speech.

\section{Focal Points}

McAdams implies that when public and private voices compete in the setting of a focal point, the government's voice typically prevails because it is "louder" $(2015,123)$. He provides, sometimes implicitly, four reasons for law's relative loudness: law "is the only expression with sanctions" (124), law is less ambiguous than informal order (109-17), law tends to be better known than private alternatives (63), and law inherently is more legitimate (123-24).

The first two of these reasons are debatable at best. McAdams (1997) has himself emphasized that norms can be backed with potentially potent informal sanctions. Nor is law invariably a relatively clear source of rules. Norms can be hard-edged. Examples are "shake hands with your right hand," and "iron holds the whale" (Ellickson 1991, 198-201). And lawmakers may deliberately choose muddy rules (Rose 1988), for example, "reasonableness" standards.

More plausible are McAdams's assertions that law tends to be relatively well publicized and relatively legitimate. Yet, as McAdams (2015) himself repeatedly shows (see especially 42-48), many focal points actually are provided not by governments, but by one or another of the institutions of civil society. Individuals may honor a private focal point rather than a public one for two basic reasons. They may deem a government to be relatively incompetent at the task at hand, or they may be largely ignorant of government pronouncements.

\section{Relative Governmental Incompetence}

In many contexts, the populace appears to regard governments as inferior institutions for establishing focal points. ${ }^{8}$ Members of a closely-knit group are particularly likely to conclude that they, partly on account of their local knowledge, would be

8. On the norms that govern how people should choose among competing providers of rules (or focal points), see Ellickson (1991, 240-64). 
better than lawmakers at establishing rules to govern their activities (Ellickson 1991, 191-206). When members of a closely knit group adopt written rules, they commonly look to the offerings of private norm entrepreneurs, not to governments. Examples are Robert's Rules of Order (McAdams 2015, 113) and the Bluebook system of legal citation.

Members of large, diffuse groups also commonly use focal points generated by extralegal sources. In the United States, the English language is a crucial medium of cooperation. Yet, as McAdams (2015, 107-09) himself observes, control over the English language in practice has been decentralized to the general public. Customary linguistic practices are somewhat regularized by norm entrepreneurs, such as the authors of dictionaries, textbooks, and The Chicago Manual of Style. There is no groundswell of political support, in the United States, for state supervision of the production of language, in contrast to the situation in France, where the Académie française has policed usage since 1637 .

The large and diffuse scientific community in the United States similarly has adopted a nongovernmental system of weights and measures (McAdams 2015, 69-70). Largely on account of lobbying by various US manufacturers, Congress has declined to adopt the metric system to replace the traditional, and far more computationally challenging, US system (Mihm forthcoming). An observer as astute as McAdams is aware that a government captured by an interest group might do a relatively poor job of proclaiming a focal point $(2015,162)$. US scientists, knowing that Congress might err, have spontaneously chosen to embrace the metric system despite its lack of congressional blessing.

McAdams mentions the possibility that a government focal point would be inherently more legitimate than a competing private alternative (2015, 124-27). Although this is facially plausible, both Schauer (2015, 65-67) and McAdams (2015, 64-67, 119-22) adduce evidence that casts doubt on the proposition that law is inherently legitimate. Congress's failure to repudiate the US system of weights and measures, for example, seems not to have damped scientists' willingness to embrace the metric system. ${ }^{9}$ Focal points plainly can be established by norm, and when they are, private norm entrepreneurs and opinion leaders commonly will have played outsized roles in the creation of these coordinating mechanisms (Ellickson 2001). Given the high level of cynicism about government, in some contexts might not a papal declaration, or the opinions of a blogger or newspaper columnist, be louder than the expressions of government officials?

\section{Ignorance of Governmental Actions}

As McAdams fully recognizes $(2015,62,86)$, a government is unlikely to succeed in establishing a focal point when its voice is scarcely heard. Governments make conspicuous efforts to communicate some laws, such as traffic rules, one of his recurring examples. State agents paint roadways and post signs and traffic lights in rights-of-way. A government similarly may post a sign listing its rules of behavior in a park (McAdams 2015, 236), and make efforts to publicize tax laws.

9. US law explicitly authorizes the use of systems of weights and measures other than the US system. 
But many governmental expressions receive scant publicity. As previously noted, numerous studies have found that, in many contexts, public awareness of legal rules is minimal. ${ }^{10}$ Contrary to what McAdams implies, neighbors are highly unlikely to be aware of the legal rules that govern the removal of vegetation encroaching across a boundary line $(2015,86-87)$, or the rights of an innocent purchaser who buys a stolen object from a thief (117-18). A motorist entering a city seldom observes signage that publicizes the entered jurisdiction's idiosyncratic legal policies. And municipal Web sites are unlikely to highlight laws that McAdams features in his discussion, such as pooper-scooper ordinances $(2015,86)$ and policies governing breast-feeding in public (197). Members of a disproportionately affected subculture, such as dog owners or maternity organizations, conceivably might help propagate knowledge of special laws of this sort, but McAdams generally underestimates the difficulties that government lawmakers have in communicating with the general public.

\section{Information Signaling}

In his latter chapters, McAdams (2015) systematically and insightfully demonstrates that the enactment of a new law may provide information of a variety of sorts. However, many private actors-including columnists, bloggers, academicians, and members of the clergy-also devote much of their energy to information production and circulation. Although the enactment of legislation can provide information about a shift in public opinion (what McAdams calls "attitudinal signaling"), so can, as he mentions (145-46), the reports of a private polling firm. Similarly, while the passage of antismoking legislation might enlighten the public about the dangers of smoking ("risk signaling"), so might a televised interview with a specialist in lung cancer.

So why, if at all, might a legislature be more competent than private speakers at providing information? McAdams stresses two factors: expertise and aggregation $(2015,155)$. Politicians certainly are relatively expert both in trends in public opinion (141-43) and in voters' intensities of preference (146), but, as McAdams himself repeatedly notes $(144-45,152,162)$, politicians' pronouncements commonly give excessive weight to the preferences of members of well-organized special interests. It is certainly true, as McAdams points out (162), that the members of a legislature commonly are numerous, but so would be the signers of a petition circulated among academic specialists and published in a prominent newspaper. I salute McAdams for his insights in these chapters, but I wish he had done more to identify the contexts in which members of the public may think government officials would be more informative than esteemed private pundits.

\section{THE ROLE OF BUSINESS ENTERPRISES AND MEMBERSHIP ASSOCIATIONS IN MAKING AND ENFORCING RULES}

It is useful to think of the legal system as a subpart of a larger system of social control. In general, the overall system is structured to induce individuals to refrain 
TABLE 1.

Components of the System of Social Control

\begin{tabular}{lcr}
\hline CONTROLLER & RULES & SANCTION \\
\hline $\begin{array}{l}\text { 1. First-Party Control } \\
\text { Actor }\end{array}$ & internalized norms; personal ethics & self-sanction \\
$\begin{array}{l}\text { 2. Second-Party Control } \\
\text { Person Acted Upon }\end{array}$ & norms, contracts & personal self-help \\
3. Third-Party Control & norms & vicarious self-help \\
a. Diffuse Social Forces & organization rules \\
b. Organizations & law & organization enforcement \\
c. Governments & & state enforcement \\
\hline
\end{tabular}

from antisocial behavior and to engage in prosocial behavior. Drawing on prior work (Ellickson 1991, 131), I provide a taxonomy, in Table 1, of the major components of the overall system. The various components identified in Table 1 are hardly insulated from one another. For example, law may borrow rules from norms (custom), and, conversely, legal innovations may influence norms.

As noted in the Introduction, legal centralists tend to exaggerate the role of law (3c in Table 1) in the system writ large. Cooperative outcomes commonly eventuate from other influences. In many contexts, first-party controls, such as selfenforced norms inculcated during childhood by parents and teachers, are particularly potent. Also important are the forces that Schauer underplays, namely, personal and vicarious acts of self-help ( 2 and $3 a$ in Table 1$)$.

Included among the potential controllers in Table 1 are nonstate organizations (3b). ${ }^{11}$ Organizations can be roughly divided into two types: business enterprises and membership associations. Business enterprises are for-profit and nonprofit entities that produce goods or services sold to outsiders. Enterprises commonly promulgate and enforce rules to control their employees. Some of the most salient rules that bind law professors, for example, are organizational rules governing the extent of teaching responsibilities and when exam grades are due.

Membership associations, typically nonprofit, provide services not to outsiders but to members. Examples are homeowners' associations, labor unions, professional associations, religious organizations, and sports leagues. A nation's civil society consists largely of these associations, in which membership commonly is voluntary. Like business enterprises, membership associations are much entwined with law. The state may attempt to regulate their structure and behavior, and courts may entertain a member's challenges to an association's rules or procedures (Harvard Law Review 1963; Tushnet 2000).

Schauer and McAdams both discuss organizations-membership associations in particular-but seem puzzled about how to characterize their rules. Schauer

11. See generally Ellickson (1991, 248-49; 2016). 
characterizes organization rules as "nonstate law" (2015, 161-67). ${ }^{12}$ McAdams uses the phrase "soft law" $(2015,112-14)$. But law is a misleading label for these constraints. Except in rare instances, such as state-run business enterprises, state officials do not draft these rules, and are seldom first-line enforcers of them.

In general, social control by a business enterprise is more legally regulated than social control by a membership organization. Employment law, for example, may constrain the methods that an enterprise uses to control its workers. To a social-control theorist, the efforts of employers to regulate workers' off-the-job behavior are particularly intriguing. An application form for employment may ask the applicant to list criminal convictions. In 2001, Yale University fired a tenured professor guilty of off-campus sexual misconduct (Folk 2001). These policies likely arise largely out of managers' concerns for their enterprise's reputation and internal security. Organization-imposed penalties operate essentially as add-ons to criminal sanctions. A functionalist analysis of the criminal justice system would take them into account.

A membership association is less likely than a business enterprise to engage in social control. Many membership associations are weak, in the sense that they make little or no effort to either make or enforce general rules of conduct (Ellickson 2016, 253-63). Consider the Law and Society Association. It holds an annual meeting, publishes a journal, and provides other services to dues-paying members. But it does not promulgate a generally applicable rulebook, such as a code of ethics, to govern its members. The Modern Language Association (2015), by contrast, has a code of ethics, which includes a rule against plagiarism. But many association codes of this stripe are purely hortatory, that is, not coupled with a mechanism for association enforcement.

Some membership associations, however, are strong in that they engage in both rule making and rule enforcement. A homeowners' association, for example, may be empowered to evict a member who has harassed other residents in violation of the association's rules of conduct (40 West 67th Street v. Pullman 2003). The New York Diamond Dealers Club is a notable example of an association with extensive rule-making and adjudicatory powers over its members (Bernstein 1992). Sports leagues actively engage in social control. The National Football League (NFL), for example, disciplines players for behavior both on and off the field of play. Following a notorious off-field incident involving running back Ray Rice, the NFL adopted rules to empower itself prospectively to suspend a player guilty of offfield domestic violence. ${ }^{13}$

Organizations differ significantly from governments. They are formed and terminated through different procedures, and are governed according to structures other than those characteristic of a representative democracy. In addition, a government invariably is linked to a particular territory, while an organization commonly is not. Why might individuals prefer that an organization, rather than a

12. See also Schauer's discussions of a school rule requiring teachers to blind grade (64), WTO and the Mafia (136-37), and sports leagues and employees of a protection racket (159-61, 231-32 n23).

13. See National Football League Players Association v. National Football League (2015), which held that the new rule could not be applied retrospectively. 
state, govern a particular aspect of their lives? Several empirical studies suggest that a strong association is most likely to emerge when the members of the pertinent group anticipate that the association will outperform the state, at least from their self-interested point of view (Bernstein 1992; West 1997; Ellickson 2016, 251-61).

The place of organizations in the overall system of social control is a topic that warrants more systematic attention than it typically has received. Schauer and McAdams both had other fish to fry, and can be excused for their somewhat casual treatments of the issue.

\section{CONCLUSION}

Prior to the publication of the two books under review, both Schauer and McAdams were highly esteemed by members of the legal academy. Each of their offerings is prize-worthy, and should send their reputations further skyward. Within the legal professoriat, legal centralism is a pervasive disease. Schauer's and McAdams's cases of it are mild and, in light of their weighty accomplishments, pardonable.

\section{REFERENCES}

Acemoglu, Daron, James A. Robinson, and Rafael J. Santos. 2013. The Monopoly of Violence: Evidence from Colombia. Journal of the European Economic Association 11 (S1): 5-44.

Bernstein, Lisa. 1992. Opting Out of the Legal System: Extralegal Contractual Relations in the Diamond Industry. Journal of Legal Studies 21 (1): 115-57.

Darley, John M., Kevin M. Carlsmith, and Paul H. Robinson. 2001. The Ex Ante Function of the Criminal Law. Law $\mathcal{E}$ Society Review 35 (1): 165-90.

Ellickson, Robert C. 1991. Order Without Law: How Neighbors Settle Disputes. Cambridge, MA: Harvard University Press.

- 2001. The Market for Social Norms. American Law and Economics Review 3 (1): 1-49.

- 2016. When Civil Society Uses an Iron Fist: The Roles of Private Associations in Rulemaking and Adjudication. American Law and Economics Review 18 (2): 237-73.

Enright, Brian. 2015. Note: The Constitutional "Terra Incognita" of Discretionary Concealed Carry Laws. University of Illinois Law Review 2015 (2): 909-57.

Folk, Elyssa. 2001. Levin Fires Lasaga; Prof Appeals Ruling. Yale Daily News, March 19.

Gintis, Herbert. 2007. The Evolution of Private Property. Journal of Economic Behavior and Organization 64 (1): 1-16.

Grechenig, Kristoffal, and Martin Kolmar. 2014. The State's Enforcement Monopoly and the Private Protection of Property. Journal of Institutional and Theoretical Economics 170 (1): 5-23.

Harvard Law Review. 1963. Developments in the Law-Judicial Control of Actions of Private Associations. Harvard Law Review 76 (5): 983-1100.

Holmes, Oliver Wendell. 1897. The Path of the Law. Harvard Law Review 10 (8): 457-78.

Johnson, Nicholas J. 2006. Self-Defense? Journal of Law Economics $\mathcal{E}$ Policy 2 (2): 187-211.

Kim, Pauline T. 1997. Bargaining with Imperfect Information: A Study of Worker Perceptions of Legal Protection in an At-Will World. Cornell Law Review 83 (1): 105-60.

Kopel, David B. 2008. The Natural Right of Self-Defense: Heller's Lesson for the World. Syracuse Law Review 59 (2): 235-52.

Levinson, Sanford. 1989. The Embarrassing Second Amendment. Yale Law Journal 99 (3): 637-59.

McAdams, Richard H. 1997. The Origin, Development, and Regulation of Norms. Michigan Law Review 96 (2): 338-433. 
2015. The Expressive Powers of Law: Theories and Limits. Cambridge, MA: Harvard University Press.

Mihm, Stephen. Forthcoming. Mastering Modernity: Weights, Measures, and the Standardization of American Life. Cambridge, MA: Harvard University Press.

Modern Language Association. 2015. Statement of Professional Ethics. www.mla.org/Resources/ Research/Surveys-Reports-and-Other-Documents/Staffing-Salaries-and-Other-Professional-Issues/ Statement-of-Professional-Ethics/Read-the-Statement-Online (accessed December 21, 2015).

Polsby, Daniel D. 1986. Reflections on Violence, Guns, and the Defensive Use of Lethal Force. Law and Contemporary Problems 49 (1): 89-111.

Rasmusen, Eric. Forthcoming. Law, Coercion, and Expression: A Review Essay on Frederick Schauer's The Force of Law and Richard McAdams's The Expressive Powers of Law. Journal of Economic Literature.

Rawls, John. 1993. Political Liberalism. New York: Columbia University Press.

Rose, Carol M. 1988. Crystals and Mud in Property Law. Stanford Law Review 40 (3): 577-610.

Schauer, Frederick. 2015. The Force of Law. Cambridge, MA: Harvard University Press.

Tushnet, Mark. 2000. The Constitution of Civil Society. Chicago-Kent Law Review 75 (2): 379-415.

Weber, Max. 1946. Politics as a Vocation. In From Max Weber: Essays in Sociology, ed. H. H. Gerth and C. Wright Mills, 77-128. New York: Oxford University Press.

Wechsler, Herbert, and Jerome Michael. 1937. A Rationale of the Law of Homicide. Columbia Law Review 37 (5): 701-61.

West, Mark D. 1997. Legal Rules and Social Norms in Japan's Secret World of Sumo. Journal of Legal Studies 26 (1): 165-201.

\section{CASES CITED}

West 67th St. v. Pullman, 790 N.E.2d 1174 (2003).

National Football League Players Ass'n v. National Football League, 88 F. Supp. 3d 1084 (D. Minn. 2015). 